\title{
Differential Susceptibility of Conyza bonariensis Biotypes to Glyphosate and ALS-Inhibiting Herbicides in Argentina
}

\author{
Eduardo Puricelli1 ${ }^{*}$, Delma Faccini1, Marcelo Metzler ${ }^{2}$, Patricia Torres ${ }^{1}$ \\ ${ }^{1}$ Facultad de Ciencias Agrarias and Consejo de Investigaciones, Universidad Nacional de Rosario, Rosario, \\ Argentina \\ ${ }^{2}$ INTA Paraná, Paraná, Argentina \\ Email: ${ }^{*}$ ed.puricelli@gmail.com
}

Received 29 October 2014; revised 15 November 2014; accepted 1 December 2014

Copyright (C) 2015 by authors and Scientific Research Publishing Inc.

This work is licensed under the Creative Commons Attribution International License (CC BY).

http://creativecommons.org/licenses/by/4.0/

(c) (†) Open Access

\section{Abstract}

The aim of this study was to compare control of three stages biotypes (rosette, bolting, and reproductive stage) of Conyza bonariensis glyphosate susceptible biotype (S) and tolerant biotype (T) to glyphosate with glyphosate and mixtures of acetolactate synthase (ALS)-inhibiting. For glyphosate, the dose-response curves confirmed that injury of the biotype $T$ relative to biotype $S$ was significantly lower for both rosette and bolting stages. Resistance index (RI) for this herbicide was approximately 4 for both weed stages. At bolting, for both biotypes doses much higher than the recommended dose were required. For acetolactate synthase (ALS)-inhibiting herbicides, at the rosette stage, control of both biotypes was excellent with doses significantly lower than the recommended rate. All herbicides within this group showed a very low $I_{50}$ relative to the recommended rate. These results indicate that biotypes difficult to control with glyphosate at the rosette and bolting stage may be controlled using acetolacte synthase (ALS)-inhibiting herbicides. Control for the reproductive stage was poor. A management program based on the combination of glyphosate with pre- and post-emergence acetolactate synthase (ALS) herbicides may be effective to control the weed.

\section{Keywords}

Glyphosate, ALS-Inhibiting Herbicides, Herbicide Tolerance, Horseweed, Residual Weed Control

"Corresponding author.

How to cite this paper: Puricelli, E., Faccini, D., Metzler, M. and Torres, P. (2015) Differential Susceptibility of Conyza bonariensis Biotypes to Glyphosate and ALS-Inhibiting Herbicides in Argentina. Agricultural Sciences, 6, 22-30. 


\section{Introduction}

Conyza bonariensis (L.) Cronq. Walker is a weed annual broad-leaved species in the Asteraceae family native to South America [1], present in fallow in autumn and spring in Argentina. Previous to the widespread adoption of no-till systems, this species was confined to pastures and undisturbed areas [2]. No-till favours germination and emergence of small-seeded weed species including Conyza spp. [3]-[5] which typically emerges during the whole fallow period [6]-[8]. In the last years, applications of glyphosate in no-till fallow have increased significantly achieving initially very good control of Conyza spp. in the region of the study [9]. At present, control of some populations is difficult in many sites of the Argentine soybean region, although no glyphosate resistant Conyza spp. biotypes have been reported. The selection of these tolerant biotypes may be due to suboptimal growth stage at application [10], overreliance on glyphosate and long-term use of sublethal doses [11]. Resistance to glyphosate of $C$. bonariensis was observed for the first time in 2003 in South Africa [12]. At present, resistance to five modes of action with Conyza canadensis (L.) Cronq. and four modes of action C. bonariensis have been reported [12]. Resistance biotypes were identified in Europe [13]-[15], Brazil [16] and USA [17]. In Argentina, a better understanding of the differences in control between biotypes is essential for developing effective long-term management strategies.

The small size of weed plants at herbicide application is relevant for achieving an acceptable control as at this stage, weeds are more susceptible [18]-[21]. Glyphosate efficacy is particularly influenced by weed size [22] [23]. In some biotypes of Conyza spp., glyphosate control fails due to an inappropriate dose when there is a delay in application that allows plants to reach sizes that are difficult to kill consistently [11].

In no-tillage fallow, control of annual weeds increases by applying residual herbicides combined with glyphosate [5] [24] [25]. Many of the residual herbicides for Conyza spp. control are acetolactate synthase (ALS)inhibiting herbicides, particularly chlorimuron-ethyl, metsulfuron-methyl and diclosulam [26] [27]. Mixtures of such herbicides with glyphosate may control biotypes resistant to glyphosate [28].

Other herbicides included in this group consist of mixtures containing sulfometuron or chlorsulfuron and are less studied, so the dose for adequate control is not clear.

The aim of this study was to compare control of three stages of $C$. bonariensis biotypes susceptible and tolerant to glyphosate with glyphosate and mixtures of acetolactate synthase (ALS)-inhibiting herbicides.

\section{Materials and Methods}

Experiments were conducted at the University of Rosario Experimental Farm at Zavalla (Lat. $33^{\circ} 01^{\prime}$ S Long. $\left.60^{\circ} 53^{\prime} \mathrm{W}\right)$, Argentina.

\subsection{Identification of Biotypes}

Seeds of $C$. bonariensis were collected in ten fields sampling at least 100 plants combined into a single composite simple per field. In some of the fields, it was known that $C$. bonariensis had survived multiple glyphosate applications with reduced adverse effect and in others the population was susceptible to glyphosate. Samples were stored under room temperature in the lab and seeds were subsequently sown in trays for a preliminary study in which glyphosate was applied to the emerged plants of each population at the rosette stage. From the populations that showed low control, one biotype was chosen and designated as biotype T. Other populations confirmed to be susceptible and again, one biotype was chosen and designated as biotype S.

\subsection{Experimental Setup}

In 2012 and 2013, on April (first seeding), May (second seeding) and June (third seeding), seeds of each biotype, $\mathrm{T}$ and $\mathrm{S}$, were sown in plastic germination trays in the lab. The seedlings were allowed to establish and then transplanted into plastic pots with drainage holes (18 cm deep, $16 \mathrm{~cm}$ wide) containing a $3 \mathrm{~kg}$ sieved soil. Soil obtained from the site was sieved through a 5-mm screen and pasteurised for $24 \mathrm{~h}$ at $80^{\circ} \mathrm{C}$. Plants were transplanted in the pots in May (first seeding), and July (second seeding), each year of the experiment. Pots were kept in the open air to represent natural light and temperature conditions during fallow, and watered regularly. At approximately 2 leaf stage, plants were thinned to 1 per pot. Each pot containing a seedling was an experimental unit. The experimental design was a factorial with four replicates where the first factor was $C$. bonariensis biotype ( $\mathrm{T}$ and $\mathrm{S}$ ), the second factor was plant stage (rosette: 25 - 30 leaf stage), dry weight per plant $0.5 \mathrm{~g}$ ( $\mathrm{SE}=$ 
$0.1 \mathrm{~g})$, bolting, dry weight per plant $1.7 \mathrm{~g}(\mathrm{SE}=0.5 \mathrm{~g})$; plants $22 \mathrm{~cm}$ tall $(\mathrm{SE}=2.3 \mathrm{~cm})$, and reproductive stage, dry weight per plant $11.2 \mathrm{~g}$ ( $\mathrm{SE}=1.3 \mathrm{~g}$ ). The third factor was herbicide (glyphosate (round up), diclosulam (spider), metsulfuron-methyl $12.5 \%$ + chlorsulfuron $62.5 \%$, (finesse), and sulfometuron-methyl $15 \%$ + clorimuronethyl 20\% (ligate), the fourth subplot factor was dose ( $0 X-$ no herbicide, control, 1/16, 1/8, 1/4X, 1/2X, 1X, 2X, 4X, 8X), being $\mathrm{X}=1080 \mathrm{~g}$ a.e. $\mathrm{ha}^{-1}$ for glyphosate, $12.6 \mathrm{~g}$ a.i ha ${ }^{-1}$ for diclosulam, $11.2 \mathrm{~g}$ a.i. ha $^{-1}$ for metsulfuron-methyl $12.5 \%$ + chlorsulfuron $62.5 \%$, $35 \mathrm{~g}$ a.i. ha $^{-1}$ for sulfometuron-methyl + clorimuron-ethyl. Herbicide application was done on 12 September in 2012 and 14 September 2013 using a spray booth with flat

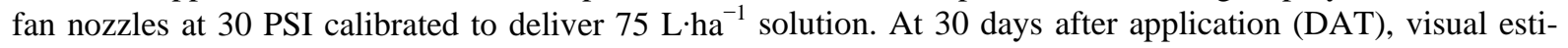
mates of plant injury relative to the nontreated control with evaluations based on $0 \%$ to $100 \%$ scale, where $0 \%$ represented no injury and 100\% complete plant death were determined, and plant weight was measured.

\subsection{Statistical Analysis.}

Correlations were made between $C$. bonariensis using visual evaluations and plant weight. The data of plant injury were subjected to a normality test before ANOVA. Because transforming the data did not change the results of analysis, the actual values are presented. Data were pooled over the years as there were no significant study-by-treatment interactions and tested for heterogeneity of variance. ANOVA was performed using R Statistical Software, R Foundation for Statistical Computing, Vienna, Austria (http://www.R-project.org) to assess the effect of plant stage, type of herbicide, herbicide dose and their interactions on plant injury ( $\mathrm{P} \leq 0.05)$. Regressions of Conyza spp. plant injury ratings over herbicide dose were performed using a four-parameter log-logistic model as described by [29] and indicated below:

$$
\mathrm{y}=\mathrm{C}+(\mathrm{D}-\mathrm{C}) / 1+\left(\mathrm{x} / \mathrm{I}_{50}\right)^{\mathrm{b}}
$$

where $\mathrm{y}$ is the response (e.g., percentage of plant injury), $\mathrm{C}$ is the lower limit, $\mathrm{D}$ is the upper limit, $\mathrm{b}$ is the slope of the line, $\mathrm{x}$ is the herbicide dose, and $\mathrm{I}_{50}$ is the rate resulting in a $50 \%$ response (e.g., $50 \%$ injury, which is also known as the $50 \%$ effective dose $\left(\mathrm{ED}_{50}\right)$. Analysis of the dose-response curves and $90 \%$ effective dose $\left(\mathrm{ED}_{90}\right)$ values was completed using the statistical software R 2.12.1 (R Statistical Software, R Foundation for Statistical Computing, Vienna, Austria http://www.R-project.org) and $d r c$ package, as described by [30]. For the reproductive stage, control was lower than $100 \%$ even for the $8 \mathrm{X}$ dose and data did not fit the dose-response curve model.

\section{Results}

A correlation of $\mathrm{r}=0.99 ; \mathrm{P} \leq 0.01$ was obtaineb between $C$. bonariensis control at 30 DAT using visual evaluations and plant weight determinations. Therefore, only visual evaluations are presented. No significant interactions were detected in the analysis between years for any of the variables so data were pooled over the experiments for each biotype. A significant interaction occurred between herbicides, dose and growth stage for both biotypes. All herbicides achieved $100 \%$ of control with the $8 \mathrm{X}$ dose or lower, for rosette and bolting stages. At the reproductive stage, control was lower than $100 \%$ even with the $8 \mathrm{X}$ dose and thus this stage was not considered to build the dose-response curves.

For glyphosate with the recommended dose (1X), control at the rosette stage was $100 \%$ for biotype $\mathrm{S}$ and $80 \%$ for biotype T (Figure 1). At bolting, control was $100 \%$ for biotype $S$ and $77 \%$ for biotype $\mathrm{T}$ (Figure 1). Injury symptoms were characterized by leaf chlorosis followed by necrosis of the tissue.

For the $\mathrm{S}$ biotype, the $\mathrm{I}_{50}$ relative to the recommended rate was $0.08 \mathrm{X}$ at the rosette stage and $0.17 \mathrm{X}$ for the bolting stage, whilst for the $\mathrm{T}$ biotype, $\mathrm{I}_{50}$ corresponded to $0.28 \mathrm{X}$ at the rosette stage and $0.80 \mathrm{X}$ for the bolting stage.

Resistance Index (RI) is defined as the ratio of $\mathrm{I}_{50}$ values relative to that of a susceptible population or recommendation dosage. Resistant index at the rosette stage was approximately 4 for both weed stages.

$\mathrm{I}_{90}$, relative to the recommended dose, was $0.18 \mathrm{X}$ for the $\mathrm{S}$ biotype at the rosette stage and $1.33 \mathrm{X}$ for the bolting stage, whilst for the $\mathrm{T}$ biotype, was $1.39 \mathrm{X}$ for the rosette stage and 11.8X for the bolting stage. This last value was fitted by the model, even though plants were $100 \%$ controlled with $8 \mathrm{X}$ (Table 1).

Dose-response curves for acetolactate synthase (ALS)-inhibiting herbicides are shown in Figures 2-4.

No differences were observed in the parameters between the $\mathrm{T}$ and $\mathrm{S}$ biotypes except for metsulfuron- 


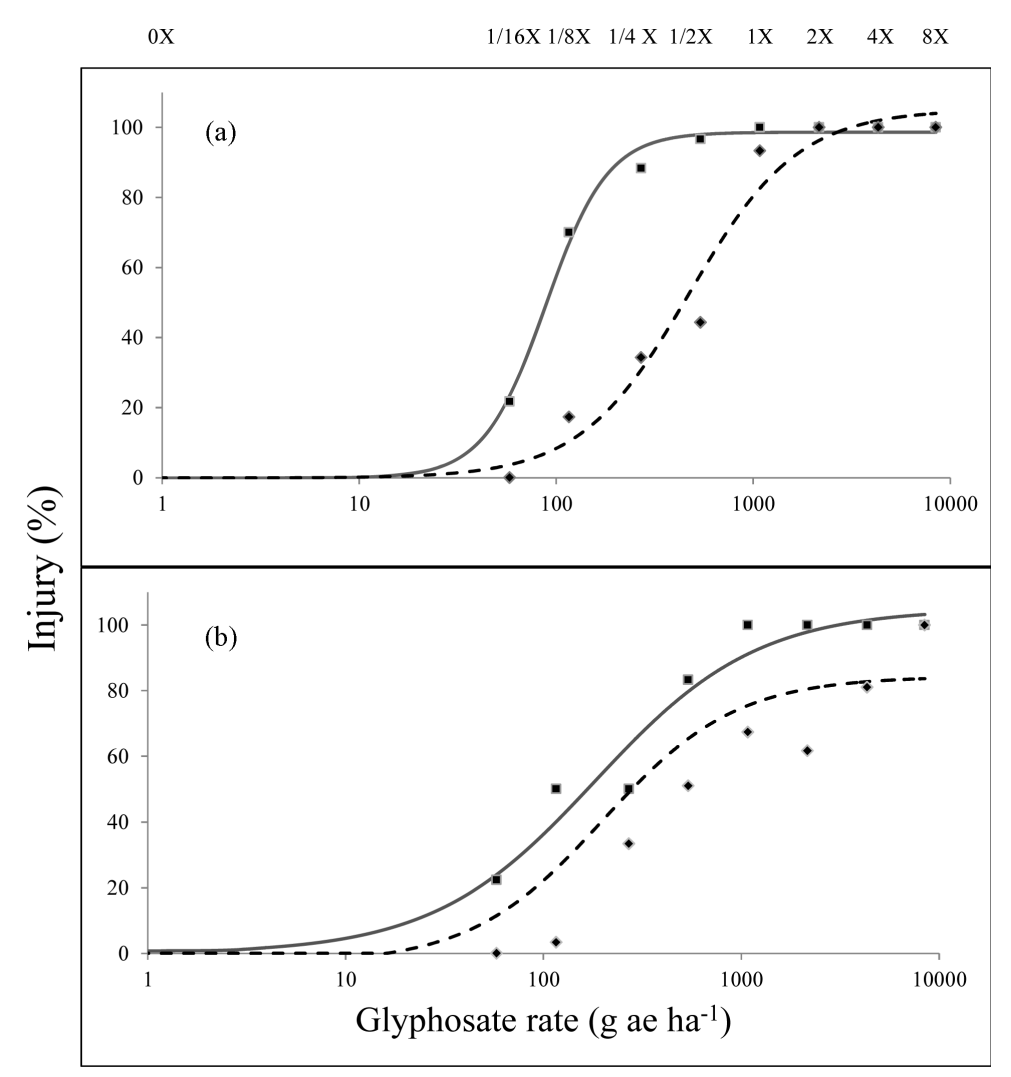

Figure 1. Dose-response (a) at rosette stage of $C$. bonariensis susceptible to glyphosate, $\mathrm{S}(\boldsymbol{\square}) \mathrm{Y}=-0.099+(98.637+0.099) /\left(1+\mathrm{e}^{((\log [\operatorname{dose}]) / 88.507) \mathrm{x}-2.754)}\right)$ and tolerant. $\mathrm{T}(\bullet) \mathrm{Y}=-0.091+(105.11+0.091) /\left(1+\mathrm{e}^{((\log [\text { dose }]) / 471.954) \mathrm{x}-1.571)}\right)$; (b) at bolting stage of $C$. bonariensis susceptible to glyphosate, $\mathrm{S}(\boldsymbol{\square}) \mathrm{Y}=$ $-0.030+(104.967+0.030) /\left(1+\mathrm{e}^{((\mathrm{B} 7 / 182.183) \mathrm{x}-1.061)}\right)$ and tolerant. $\mathrm{T}(\bullet) \mathrm{Y}=$ $-3.224+(84.360+3.224) /\left(1+\mathrm{e}^{((\mathrm{B} 13 / 199.608) \mathrm{x}-1.293)}\right)$.

Table 1. Regression parameters estimates and ED90 for glyphosate based on visual ratings at 30 days after treatment for a susceptible and a tolerant biotype of Conyza bonariensis.

\begin{tabular}{ccccccccccc}
\hline & Stage & B & C & D & $\mathrm{I}_{50}$ & $\mathrm{I}_{50}(\% \mathrm{X})$ & $\mathrm{ED}_{90}$ & $\mathrm{I}_{90}(\% \mathrm{X})$ & $\mathrm{R}^{2}$ \\
\hline Susceptible (S) & & & & & & & & & & \\
& Rosette & 2.7 & 0.1 & 98.3 & 88 & 0.08 & 194.0 & 0.18 & 96.5 \\
& Bolting & 1.0 & 0.3 & 108.1 & 182 & 0.17 & 1442.5 & 1.33 & 93.7 \\
Tolerant (T) & & & & & & & & & \\
& Rosette & -1.4 & -3.8 & 101.1 & 305.8 & 0.28 & 1501.4 & 1.39 & 95.9 \\
& Bolting & -0.8 & -2.6 & 110.8 & 861.2 & 0.80 & 12702.9 & 11.8 & 95.3 \\
\hline
\end{tabular}

methyl + chlorsulfuron which showed higher injury of the biotype $\mathrm{T}$ relative to biotype $\mathrm{S}$ at low doses for the rosette stage (Table 2).

At the rosette stage, for all the herbicides of this group, $\mathrm{I}_{50}$ ranged between 0.02 and $0.14 \mathrm{X}$.

For each weed stage and for each herbicide, no significant differences for $\mathrm{I}_{50}$ between $\mathrm{S}$ and $\mathrm{T}$ biotypes were observed. At rosette stage, values of $\mathrm{I}_{50}$ were in average for both biotypes $1.7(0.13 \mathrm{X})$ for diclosulam, $0.5(0.01 \mathrm{X})$ for metsulfuron-methyl + chlorsulfuron and $2.1(0.19 \mathrm{X})$ for sulfometuron-methyl + clorimuron-ethyl. At bolting, 7.3 (0.58X) for diclosulam, $(0.15 \mathrm{X})$ for metsulfuron-methyl + chlorsulfuron and $(0.52 \mathrm{X})$ for sulfometuron- 


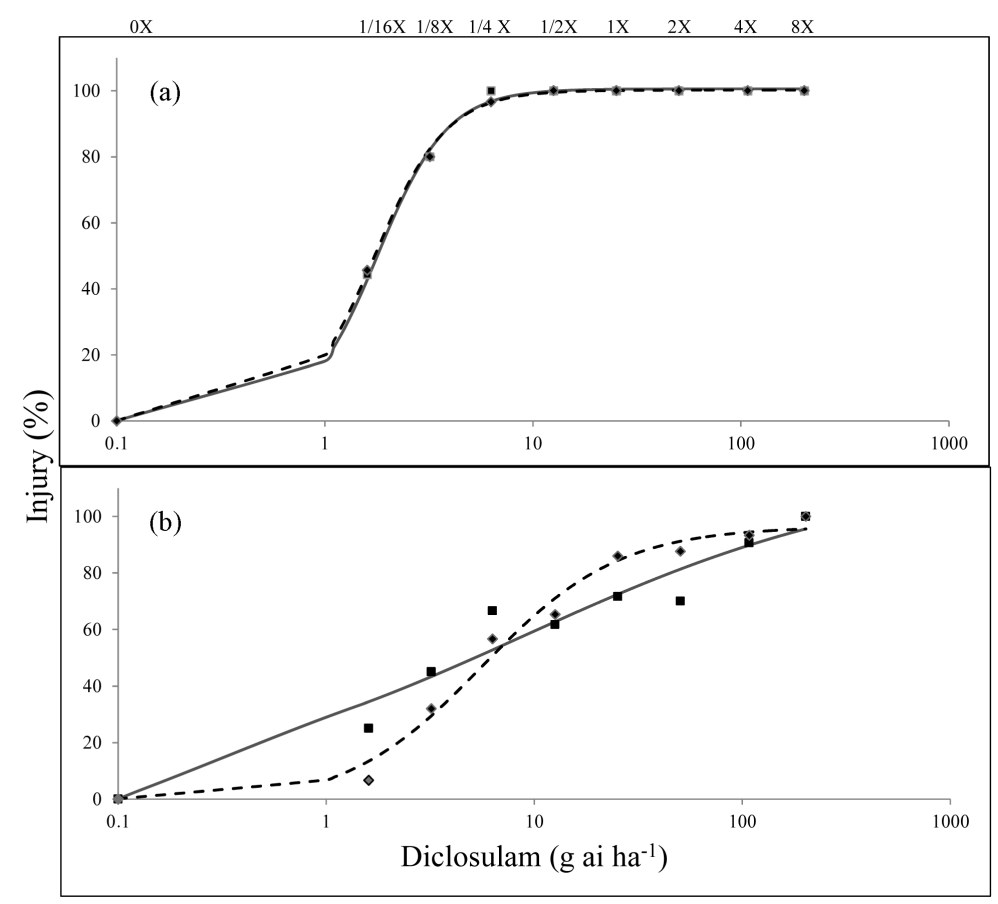

Figure 2. Dose-response (a) at stage rosette of $C$. bonariensis susceptible to diclosulam, S $\left(\right.$ ( ) $\mathrm{Y}=-0.102+(100.568+0.102) /\left(1+\mathrm{e}^{((\log [\text { dose }]) / 1.793) x-2.584)}\right)$ and a tolerant. T $(\diamond) \mathrm{Y}=-0.100+(100.183+0.100) /\left(1+\mathrm{e}^{((\log [\text { dose }]) / 1.734) ;-2.513)}\right)$ (b) At stage bolting of $C$. bonariensis susceptible to diclosulam, $\mathrm{S}(\boldsymbol{\square}) \mathrm{Y}=$ $-0.200+(116.163+0.200) /\left(1+\mathrm{e}^{((\log [\mathrm{dose}] / 9.0437) ;-0.495)}\right)$ and tolerant. $\mathrm{T}(\bullet) \mathrm{Y}=$ $-2.463+(96.424+2.463) /\left(1+\mathrm{e}^{((\log [\operatorname{dose} e / 5.6154189) ;-1.3167961)}\right)$.

Table 2. Regression parameters estimates and ED90 for the different ALS-inhibiting herbicides based on visual ratings at 30 days after treatment for a susceptible and a tolerant biotype of Conyza bonariensis.

\begin{tabular}{ccccccccccc}
\hline & Stage & $\mathrm{B}$ & $\mathrm{C}$ & $\mathrm{D}$ & $\mathrm{I}_{50}$ & $\mathrm{I}_{50}(\% \mathrm{X})$ & $\mathrm{ED}_{90}$ & $\mathrm{I}_{90}(\% \mathrm{X})$ & $\mathrm{R}^{2}$ \\
\hline Susceptible (S) & & & & & & & & & & \\
\hline Diclosulam & Rosette & 2.6 & 0.1 & 100.5 & 1.8 & 0.13 & 4.2 & 0.33 & 96.1 \\
& Bolting & 0.5 & 0.2 & 116.2 & 9.1 & 0.72 & 761.9 & 60.5 & 90.4 \\
Metsulfuron-methyl + chlorsulfuron & Rosette & 1.9 & 0.1 & 99.9 & 0.8 & 0.07 & 2.5 & 0.22 & 94.8 \\
& Bolting & 05 & 0.2 & 122.8 & 6.1 & 0.54 & 433.8 & 38.7 & 94.8 \\
Sulfometuron-methyl + clorimuron-ethyl & Rosette & 1.9 & 0.1 & 101.2 & 2.4 & 0.07 & 7.5 & 0.21 & 94.1 \\
& Bolting & 0.4 & 0.1 & 117.7 & 5.1 & 0.15 & 924.3 & 26.4 & 92,5 \\
\hline Tolerant (T) & & & & & & & & & \\
\hline Diclosulam & Rosette & 2.5 & 0.1 & 100.1 & 1.7 & 0.13 & 4.2 & 0.33 & 98.2 \\
& Bolting & 1.3 & 2.5 & 96.4 & 5.6 & 0.44 & 29.79 & 2.36 & 94.5 \\
\hline \multirow{2}{*}{ Metsulfuron-methyl + chlorsulfuron } & Rosette & 1.0 & 0.1 & 101.0 & 0.19 & 0.02 & 1.69 & 0.15 & 75.9 \\
& Bolting & 0.8 & 1.2 & 112.4 & 4.7 & 0.42 & 75.3 & 6.7 & 92.4 \\
\hline & Rosette & 1.8 & 0.1 & 100.9 & 1.8 & 0.05 & 6.27 & 0.18 & 94.3 \\
& Bolting & 0.6 & 0.1 & 117.5 & 6.8 & 0.19 & 430.5 & 12.3 & 89.4 \\
\hline
\end{tabular}




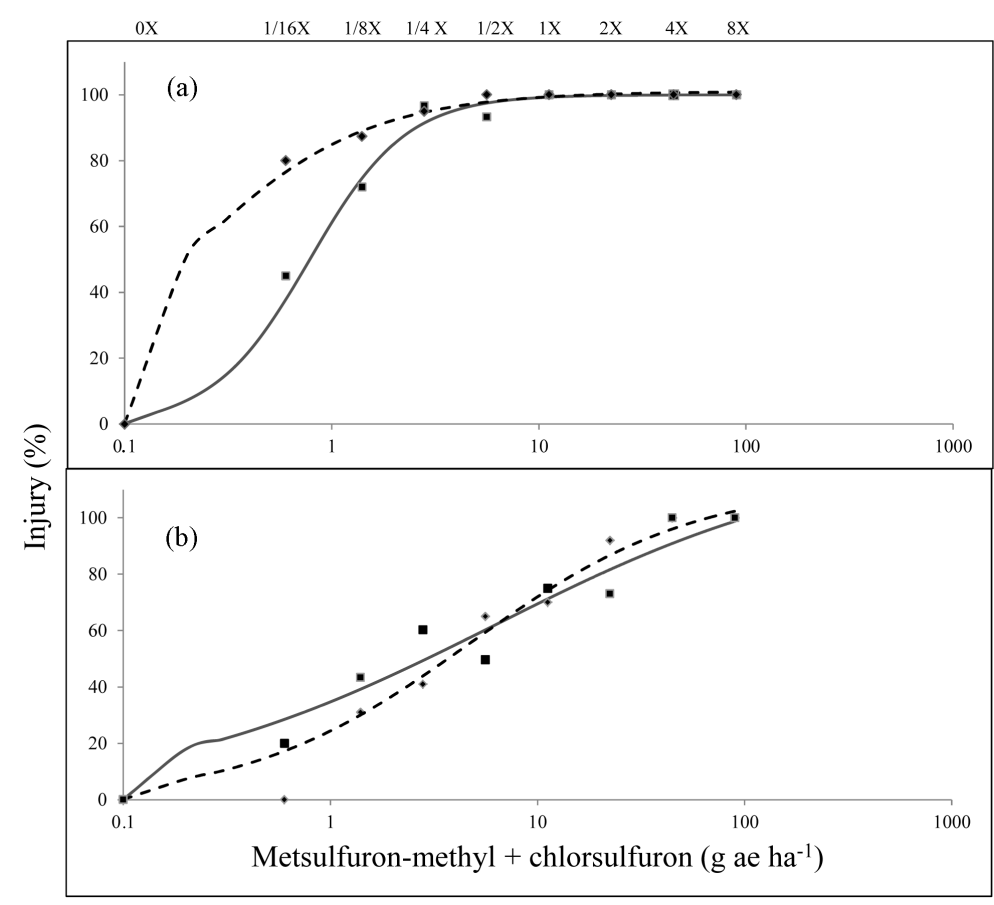

Figure 3. Dose-response (a) at stage rosette of $C$. bonariensis susceptible to metsulfuron-methyl + chlorsulfuron, $\mathrm{S}(\boldsymbol{\square}) \mathrm{Y}=-0.099+(99.990+0.099) /(1+$ $\left.\mathrm{e}^{((\log [\text { dose }] / 0.782) \mathrm{x}-1.860)}\right)$ and tolerant. $\mathrm{T}(\diamond) \mathrm{Y}=-0.100+(101.033+0.100) /(1+$ $\left.\mathrm{e}^{((\log [\operatorname{dose}] / 0.194) ;-1.014)}\right) ;$ (b) At stage bolting of $C$. bonariensis susceptible to metsulfuron-methyl + chlorsulfuron, $\mathrm{S}(\mathbf{\square}) \mathrm{Y}=-0.193+(122.776+1.005) /(1$ $\left.+\mathrm{e}^{((\log [\mathrm{dose}] / 6.126) \mathrm{x}-0.515)}\right)$ tolerant. $\mathrm{T}(\bullet) \mathrm{Y}=-1.220+(112.368+1.220) /(1+$ $\left.\mathrm{e}^{((\log [\operatorname{dose}] / 4.729) x-0.793)}\right)$.

methyl + clorimuron-ethyl. Injury sympthoms were characterized by stunting, purpling, general yellowing of new growth, terminal bud death.

$\mathrm{I}_{90}$ relative to the recommended dose for the rosette stage for diclosulam was $0.25 \mathrm{X}$ for the $\mathrm{S}$ and $\mathrm{T}$ biotype, for metsulfuron-methyl + chlorsulfuron was $0.22 \mathrm{X}$ for S biotype and 0.15 for the $\mathrm{T}$ biotype, for sulfometuronmethyl + clorimuron-ethyl was $0.21 \mathrm{X}$ and $0.18 \mathrm{X}$. At bolting for diclosulam was $60 \mathrm{X}$ for the $\mathrm{S}$ and $2 \mathrm{X}$ for the $\mathrm{T}$ biotype, for metsulfuron-methyl + chlorsulfuron was $0.41 \mathrm{X}$ for $\mathrm{S}$ biotype and 6.70 for the $\mathrm{T}$ biotype, for sulfometuron-methyl + clorimuron-ethyl was 0.26 for $\mathrm{S}$ biotype and $0.12 \mathrm{X}$ for $\mathrm{T}$ biotype. The value of $60 \mathrm{X}$ for diclosulam was fitted by the model, even though plants were $100 \%$ controlled with $8 \mathrm{X}$.

At the reproductive stage plants were well developed and lignified at application time and control was poor for all the herbicides and doses. All these plants survived, flowered and produced abundant seeds (data not shown).

Results of the experiments provided evidence that $C$. bonariensis at the rosette stage the biotype $\mathrm{S}$ is easily controlled by both, glyphosate and the acetolactate synthase (ALS)-inhibiting herbicides studies whilst the biotype $\mathrm{T}$, showed low response to glyphosate although it is sensitive to the ALS inhibiting herbicides.

\section{Discussion}

The dose-response curves confirmed that injury of the biotype T relative to biotype $\mathrm{S}$ was significantly lower for both growth stages which concurs with other studies in C. canadensis [7].

Plant stage at application time is a key factor which greatly affects glyphosate efficacy and weed control is higher at the first stages of weed development [31]. In C. bonariensis, in the present study, the glyphosate dose required for control increased as a function of plant age as was also observed with other studies in this species [13] and in C. canadensis [23].

Resistance factors for glyphosate were similar or lower (approximately 4 for both weed stages) relative to other studies in C. bonariensis which showed resistance factors about 7 and 9 [13] or ranged between 3 - 9 [17]. 


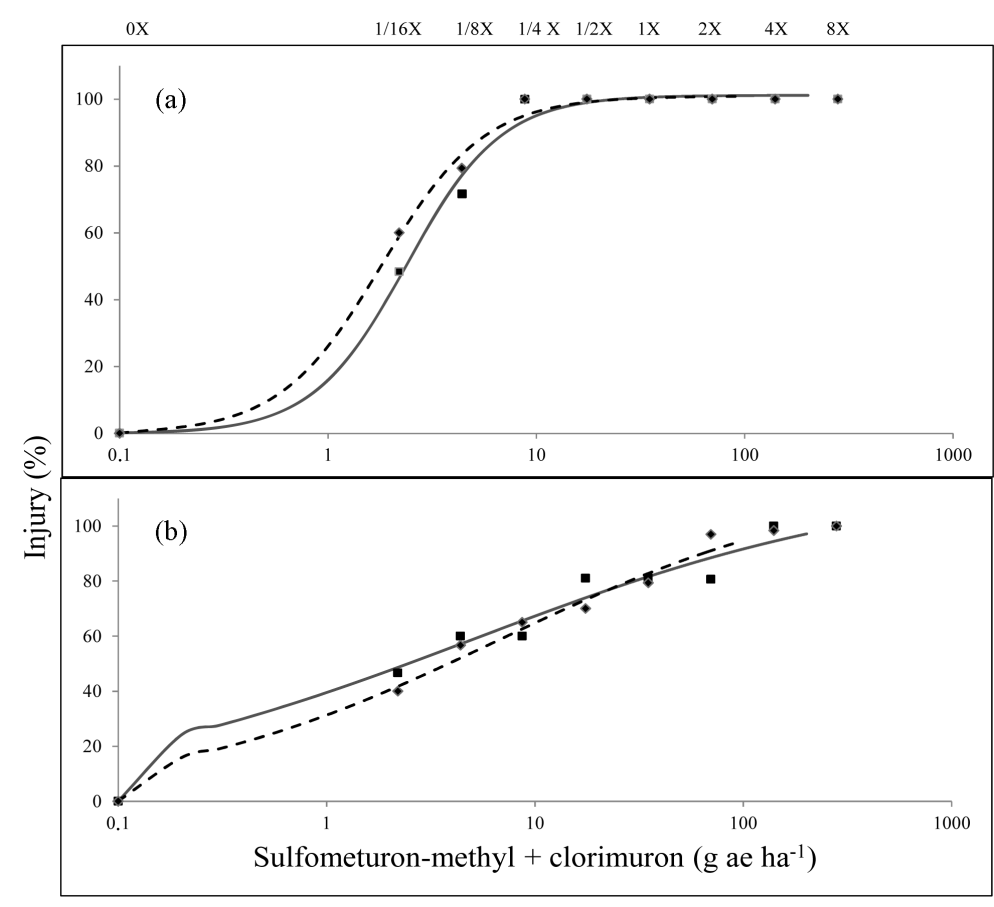

Figure 4. Dose-response (a) at stage rosette of $C$. bonariensis susceptible to sulfometuron-methyl + clorimuron-ethyl, $\mathrm{S}(\mathbf{\square}) \mathrm{Y}=-0.101+(101.172+$ $0.101) /\left(1+\mathrm{e}^{((\log [\text { dose }] / 2.387) x-1.917)}\right)$ and tolerant. $\mathrm{T}(\bullet) \mathrm{Y}=-0.101+(100.922+$ $0.101) /\left(1+\mathrm{e}^{((\log [\mathrm{dose}] / 1.811) \mathrm{x}-1.767)}\right)$; (b) at stage bolting of $C$. bonariensis susceptible to sulfometuron-methyl + clorimuron-ethyl, $\mathrm{S}(\boldsymbol{\square}) \mathrm{Y}=-0.096+$ $(117.731+0.096) /\left(1+\mathrm{e}^{((\log [\text { dose }] / 5.0230) \mathrm{x}-0.421)}\right)$ and tolerant. $\mathrm{T}(\diamond) \mathrm{Y}=0.029+$ $(117.558-0.029) /\left(1+\mathrm{e}^{((\log [\operatorname{dose}] / 6.784) \mathrm{x}-0.529)}\right)$.

In those studies, resistance has arisen in orchards or vineyards after multiple applications of glyphosate as the only herbicide. In the soybean region in Argentina, glyphosate is mostly applied in fallows and in soybeans one or two times per year, which may account for the lower resistance factor of $C$. bonariensis. At bolting, acceptable ( $>90 \%$ ) control, for the $S$ biotype and the $\mathrm{T}$ biotype at both stages requires doses much higher than the recommended use dose, thus, application of glyphosate at these levels is not economical.

Acetolactate synthase (ALS)-inhibiting herbicides, at the rosette stage, provided control of the biotype $\mathrm{S}$ of $C$. bonariensis at doses significantly lower than the recommended rate. In other studies, acetolactate synthase (ALS)-inhibiting herbicides were also used in combination with glyphosate in fallows previous to soybean planting achieving adequate control of small size plants of Conyza spp. [4]. Herbicides of this group provide residual control and may help to reduce new seedling flushes not controlled by glyphosate alone [5].

At the reproductive stage, control with glyphosate and acetolactate synthase (ALS)-inhibiting herbicides was very low, thus, a new application of a postemergence herbicide with alternate mode of action is needed ("double knock" technique) [32] [33].

From these results it is clear that plants from $C$. bonariensis populations tolerant to control with glyphosate may be controlled using acetolactate synthase (ALS)-inhibiting herbicides. Among the herbicides within this group, diclosulam at the rosette stage showed the lowest $\mathrm{ED}_{50}$ relative to the recommended rate and showed complete control at $0.5 \mathrm{X}$. In another study, a biotype of $C$. bonariensis resistant to glyphosate was also sensitive to metsulfuron-methyl and clorimuron-ethyl, both acetolactate synthase (ALS)-inhibiting herbicides [16]. However, [28] and [31] found that C. canadensis exhibited multiple resistance to glyphosate and acetolactate synthase (ALS)-inhibiting herbicides such as cloransulam indicating that, it is necessary to adopt an adequate management of chemical control to avoid resistance to this mode of action.

\section{References}

[1] Burkart, A. (1974) Flora Ilustrada de Entre Ríos (Argentina). Tomo VI. Colección Científica del INTA, Buenos Aires, 
219-228.

[2] Tuesca, D. and Puricelli, E. (2007) Effect of Tillage Systems and Herbicide Treatments on Weed Abundance and Diversity in a Glyphosate Resistant Crop Rotation. Crop Protection, 26, 1765-1770. http://dx.doi.org/10.1016/j.cropro.2007.03.008

[3] Moseley, C.M. and Hagood Jr., E.S. (1990) Horseweed (Conyza canadensis) Control in Full-Season No-Till Soybeans (Glycine max). Weed Technology, 4, 814-818.

[4] Davis, V.M., Gibson, K.D., Bauman, T.T., Weller, S.C. and Johnson, W.G. (2007) Influence of Weed Management Practices and Crop Rotation on Glyphosate-Resistant Horseweed Population Dynamics and Crop Yield. Weed Science, 55, 508-516. http://dx.doi.org/10.1614/WS-06-187.1

[5] Davis, V.M., Gibson, K.D., Bauman, T.T., Weller, S.C. and Johnson, W.G. (2009) Influence of Weed Management Practices and Crop Rotation on Glyphosate-Resistant Horseweed (Conyza canadensis) Population Dynamics and Crop Yield-Years 111 and 1V. Weed Science, 57, 417-426. http://dx.doi.org/10.1614/WS-09-006.1

[6] Buhler, D.D. and Owen, M.D.K. (1997) Emergence and Survival of Horseweed (Conyza canadensis). Weed Science, 45, 98-101.

[7] Nandula, V.K., Eubank, T.W., Poston, D.H., Koger, C.H. and Reddy, K.N. (2006) Factors Affecting Germination of Horseweed (Conyza canadensis). Weed Science, 54, 898-902. http://dx.doi.org/10.1614/WS-06-006R2.1

[8] Main, C.L., Steckel, L.E., Hayes, R.M. and Mueller, T.C. (2006) Biotic and Abiotic Factors Influence Horseweed Emergence. Weed Science, 54, 1101-1105. http://dx.doi.org/10.1614/WS-06-026R1.1

[9] Puricelli, E. and Tuesca, D. (2005) Efecto del sistema de labranza sobre la dinámica de la comunidad de malezas en trigo y en barbechos de secuencias de cultivos resistentes a glifosato. Agriscientia, 2, 69-78.

[10] Shrestha, A., Hembree, K.J. and Va, N. (2007) Growth Stage Influences Level of Resistance in Glyphosate-Resistant Horseweed. California Agriculture, 61, 67-70. http://dx.doi.org/10.3733/ca.v061n02p67

[11] Sansom, M., Saborido, A. and Dubois, M. (2013) Control of Conyza spp. with Glyphosate-A Review of the Situation in Europe. Plant Protection Science, 49, 44-53.

[12] Heap, I. (2014) International Survey of Herbicide Resistant Weeds. http://www.weedscience.com

[13] Urbano, J.M., Borrego, A., Torres, V., Leon, J.M., Jimenez, C., Dinelli, D. and Barnes, J. (2007) Glyphosate-Resistant Hairy Fleabane (Conyza bonariensis) in Spain. Weed Technology, 21, 396-401. http://dx.doi.org/10.1614/WT-06-096.1

[14] Dinelli, G., Marotti, I., Bonetti, A., Catizone, P., Urbano, J.M. and Barne, J. (2008) Physiological and Molecular Bases of Glyphosate Resistance in Conyza bonariensis Biotypes from Spain. Weed Research, 48, 257-265. http://dx.doi.org/10.1111/j.1365-3180.2008.00623.x

[15] Travlos, I.S. and Chachalis, D. (2010) Glyphosate-Resistant Hairy Fleabane (Conyza bonariensis) Is Reported in Greece. Weed Technology, 24, 569-573. http://dx.doi.org/10.1614/WT-D-09-00080.1

[16] Vargas, L., Bianchi, M.A., Rizzardi, M.A., Gostinetto, D. and Dalmagro, T. (2007) Buva (Conyza bonariensis) resistente ao glyphosate na região sul do Brasil. Planta Daninha, 25, 573-578. http://dx.doi.org/10.1590/S0100-83582007000300017

[17] Okada, M. and Jasieniuk, M. (2014) Inheritance of Glyphosate Resistance in Hairy Fleabane (Conyza bonariensis) from California. Weed Science, 62, 258-266. http://dx.doi.org/10.1614/WS-D-13-00111.1

[18] Devlin, D.L., Long, J.H. and Maddux, L.D. (1991) Using Reduced Rates of Postemergence Herbicides in Soybeans (Glycine max). Weed Technology, 5, 843-840.

[19] Klingaman, T.E., King, C.A. and Oliver, R.L. (1991) Effect of Application Rate, Weed Species, and Weed Stage of Growth on Imazethapyr Activity. Weed Science, 40, 227-232.

[20] Blackshaw, E.B. and Harker, N. (1997) Scentless Chamomile (Matricaria perforata) Growth, Development, and Seed Production. Weed Science, 45, 701-705.

[21] Faccini, D. and Puricelli, E. (2007) Efficacy of Herbicide Dose and Plant Growth Stage on Weeds Present in Fallow Ground. Agriscientia, 24, 23-29.

[22] Vanlieshout, L.A. and Loux, M.M. (2000) Interactions of Glyphosate with Residual Herbicides in No-Till Soybean (Glycine max) Production. Weed Technology, 14, 480-487. http://dx.doi.org/10.1614/0890-037X(2000)014[0480:IOGWRH]2.0.CO;2

[23] Shrestha, A., Hembree, K.J. and Va, N. (2007) Growth Stage Influences Level of Resistance in Glyphosate-Resistant Horseweed. California Agriculture, 61, 67-70. http://dx.doi.org/10.3733/ca.v061n02p67

[24] Soltani, N., Robinson, D.E., Tardif, F.J., Lawton, M.B. and Sikkema, P.H. (2013) Control of Glyphosate Resistant Canada Fleabane [Conyza canadensis (L.) Cronq.] with Preplant Herbicide Tankmixes in Soybean [Glycine max (L). Merr.]. Canadian Journal Plant Science, 93, 659-667. http://dx.doi.org/10.4141/cjps2012-320 
[25] Crespo, R.J., Bernards, M.L., Kruger, G., Lee, D. and Wilson, R. (2013) Response of Nebraska Horseweed (Conyza canadensis) Populations to Dicamba. Journal of Agricultural Science, 5, 158-164. http://dx.doi.org/10.5539/jas.v5n5p158

[26] Trainer, G.D., Loux, M.M., Harrison, S.K. and Regnier, E. (2005) Response of Horseweed Biotypes to Foliar Applications of Cloransulam-Methyl and Glyphosate. Weed Technology, 19, 231-236. http://dx.doi.org/10.1614/WT-04-127R3

[27] Santos, G., Oliveira Jr., R.S., Constantin, J., Francischini, A.C. and Osipe, J.B. (2014) Multiple Resistance of Conyza sumatrensis to Chlorimuronethyl and to Glyphosate. Planta Danhina, 32, 409-416. http://dx.doi.org/10.1590/S0100-83582014000200019

[28] Davis, V.M., Kruger, G.R., Stachler, J.M., Loux, M.M. and Johnson, W.G. (2009b) Growth and Seed Production of Horseweed (Conyza canadensis) Populations Resistant to Glyphosate, ALS-Inhibiting, and Multiple (Glyphosate + ALS-Inhibiting) Herbicides. Weed Science, 57, 494-504. http://dx.doi.org/10.1614/WS-09-024.1

[29] Seefeldt, S.S., Jensen, J.E. and Fuerst, E.P. (1995) Log Logistic Analysis of Herbicide Dose Response Relationships. Weed Technology, 9, 218-227.

[30] Knezevic, S.Z., Streibig, J.C. and Ritz, C. (2007) Utilizing R Software Package for Dose-Response Studies: The Concept and Data Analysis. Weed Technology, 21, 840-848. http://dx.doi.org/10.1614/WT-06-161.1

[31] Byker, H.P., Soltani, N., Robinson, D.E., Tardif, F.J., Lawton, M.B. and Sikkema, P.H. (2013) Glyphosate-Resistant Canada Fleabane [Conyza canadensis (L). Cronq.]: Dose Response to Glyphosate and Control with Postemergence Herbicides in Soybean in Ontario. Canadian Journal Plant Science, 93, 1187-1193. http://dx.doi.org/10.4141/cjps2013-067

[32] Werth, J., Walker, S., Boucher, L. and Robinson, G. (2010) Applying the Double Knock Technique to Control Flaxleaf Fleabane (Conyza bonariensis). Weed Biology and Management, 10, 1-8. http://dx.doi.org/10.1111/j.1445-6664.2010.00360.x

[33] Wu, H., Walker, S., Robinson, G. and Coombes, N. (2010) Control of Flaxleaf Fleabane (Conyza bonariensis) in Wheat and Sorghum. Weed Technology, 24, 102-107. http://dx.doi.org/10.1614/WT-09-043.1 
Scientific Research Publishing (SCIRP) is one of the largest Open Access journal publishers. It is currently publishing more than 200 open access, online, peer-reviewed journals covering a wide range of academic disciplines. SCIRP serves the worldwide academic communities and contributes to the progress and application of science with its publication.

Other selected journals from SCIRP are listed as below. Submit your manuscript to us via either submit@scirp.org or Online Submission Portal.
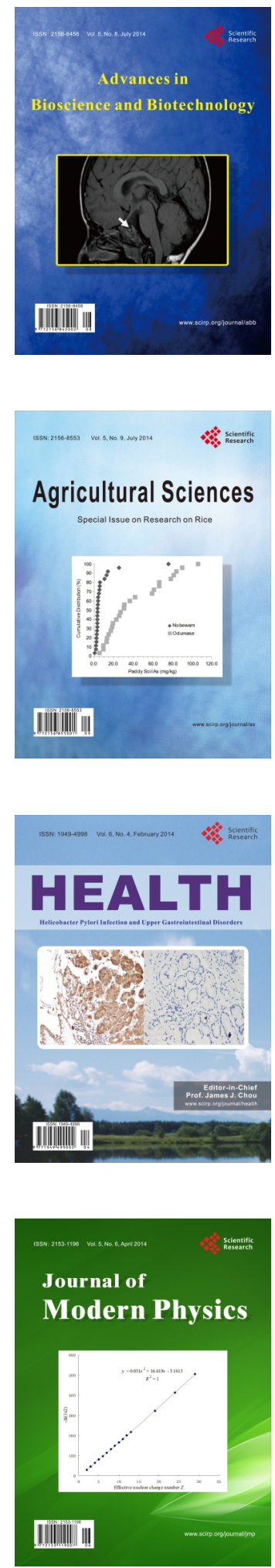
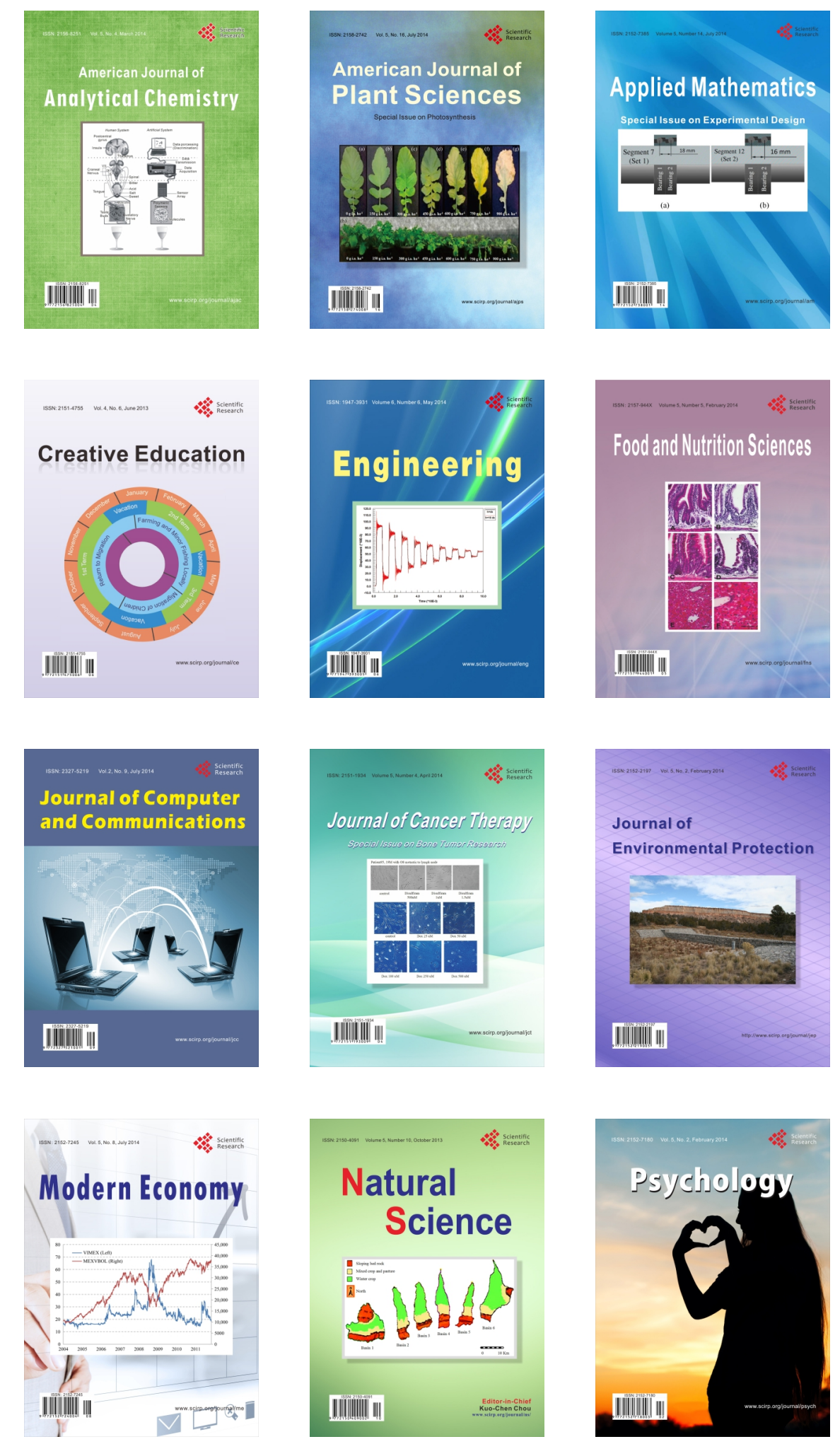